\title{
Language Learning Strategies Used by Male and Female Literature Students at Post Graduate Level
}

\author{
Muhammad Arfan Lodhi ${ }^{1}$, Farzana Ismail ${ }^{2}$, Aisha Fatima ${ }^{3}$, Numra Qayyum ${ }^{4} \&$ Hina Afsheen ${ }^{5}$ \\ ${ }^{1}$ Higher Education Department Collegiate Wing, Punjab, Pakistan \\ ${ }^{2}$ The Islamia University Bahawalpur, Pakistan \\ ${ }^{3}$ NCBA \& E University, Lahore, Pakistan \\ ${ }^{4}$ Khawaja Fareed University of Engineering and IT, Rahim Yar Khan, Pakistan \\ ${ }^{5}$ Govt. Postgraduate College for women, Rahim Yar Khan, Pakistan \\ Correspondence: Muhammad Arfan Lodhi, Higher Education Department Collegiate Wing, Punjab, Pakistan. \\ E-mail: samaritan_as@hotmail.com
}

Received: December 23, 2018 Accepted: January 15, 2019 Online Published: May 23, 2019

doi:10.5539/ells.v9n2p73 URL: https://doi.org/10.5539/ells.v9n2p73

\begin{abstract}
Language learning strategies play an important role in acquiring language proficiency skills at different levels of learning. The current study being quantitative in nature, has been carried out to investigate the role played by language learning strategies (LLS) while learning English literature at post graduate level. Therefore 160 students from three different institutions were randomly selected to participate in this survey-oriented project. An instrument originally created by Oxford (1980-1990) about Strategy inventory of learning a language (SILL) version 0.7 and further modified after piloting was distributed among the students. The findings of the sturdy reveal positive relation of strategies among the students while the females surpassed over male participants in adopting strategic use of learning. Obtained data show that there was no significant similarity found among them; but lot of differences observed regarding use of different strategies. The females were most frequent users of memory, cognitive, affective, meta-cognitive and social strategies while male learners were involved in using compensatory, cognitive and also the active users of meta-cognitive strategies. As far as difficulties during learning English literature are concerned: a lot of major aspects of language learning strategies were observed that need to be solved. On the whole, students at postgraduate level are aware of LLS and utilize these strategies while learning English language and literature.
\end{abstract}

Keywords: English proficiency, language learning strategies (LLS), post graduate level (PG), strategy inventory of language learning (SILL)

\section{Introduction}

\subsection{Rational for the Study}

Learners adopt different ways, means, techniques and strategies to acquire, memorize and retrieve knowledge. In the case of language learning strategies, the role of such techniques becomes more important to acquire the new learnable input. Some people just have desire to learn as the foremost reason to accomplish education while others take this serious process for granted but many of them have a traditional sense of the meaning of learning (Fink, 2003). According to Gass and Selinker (2008), second language learning refers to the language learned after native language and the process adopted to get fluency on second language is followed by many strategies. Language learning strategies (LLS) refer to efforts or actions that learners take consciously to achieve learning or to acquire unfamiliar knowledge, such as looking for nonverbal clues from the speaker or figuring out the meaning of a word from its context. The significance in LLS is helpful for us in solving learning problems whether they are related to input or output (Brown, 2000, p. 122). According to Gu (2003), cultural surrounding of learners normally does not affect their adopted choices of language learning strategies. However, the study shows that as compared to females, males were more inclined towards using strategies while acquiring reading proficiency. Past researches (Gu, 2003; Shmais, 2003; Koch, 2005) explored that females intend to learn vocabulary by using more strategies than male learners. Moreover, a research conducted in Russian context to unveil learning in Russian society reports that male learners' use of strategies is greater than females (Gu, 2003). 
He further explained in his study the incessant use of strategies by Chinese female learners as a forecast of the prestige of society (ibid). During the general language learning strategies, dissimilarity between males and females have been observed by Shmais (2003) where the strategies used by males are significantly much higher than females. Lee (2010) cited different factors that influence on LLS like different stages of learning, level of proficiency, motivational influence, background of culture, gender difference, styles of learning, learning aptitude and age of learners. Similarly, Graham (1997) cited the results obtained through his study on use of LLS that there is a significant difference among successful and unsuccessful learners regarding their use of language learning strategies. Furthermore, Koch (2005) mentioned that it is impossible for learners to get success in their selected goals without the use of LLS.

\subsection{Background of the Study}

There are many interpretations and explanations for the concept of learning strategies. Many previous researches reflect that the strategies used by males are higher than their female counterparts (Baily, 1996). However, many contemporary literatures of this zone show females are actively involved in using strategies than the male learners (Oxford, 1993). Although the intrinsic advantages and general concepts about second language learning concerning gender are discussed as drawback which are framed with great knowledge of strategies. However, Ehrlich (1995) cited that the folk tales unveil the dominancy of female learners in using strategies, turning them more strategic users and high-level achievers than male learners. Further researches on LLS unveil that suitable language learning strategies are beneficial for the development of correspondence, communication, proficiency improvement, and independent learning (Oxford \& Crookall, 1988, 1989; Oxford, 1990) while describing the unconventional terms used for strategies, According to Oxford and Crookall (1989), "It does not matter what they are said to be, through strategies learning has become more logical and effective" (p. 404). However, some researches indicated the interaction of variation theory and sociolinguistics methodology which cited gender influence, feminist theory as base, gender as system and variables related to other social relation. Green and Oxford (1995) stated that many pre-eminent features of LLS have been indicated through different quantitative researches. Therefore, it is understandable to get comprehensive knowledge about LLS and their relation to second language learning.

\subsection{Research Questions}

The main aim of the study was to examine the contribution of LLS in learning English Literature at university level. The emphasis was given specially to know the difference in the usage of LLS and difficulties while learning English literature at post graduate level. The primary and secondary research questions of the current study are as follows:

1) What kinds of the language learning strategies are used by students of English literature at post graduate level?

2) What similarities and differences are found among male and female students in using language learning strategies?

\subsection{Conceptual Framework}

The hallmark of the modern science is to develop a theory of cognition which has power to comprehend all human abilities related to learning and acquisition. According to the philosophers and scholars, who conducted the research on language acquisition in Western world, the main focus of the theory of language was to represent the constraints of cultural and social contexts that were carried out on middle class and adults (Fareed, 1995; Sunderland, 2000). Another study conducted by Davis and Skilton (2004) mentions the theorist and researchers who consider classrooms, societies and communities as the main aspects having the relationship between gender and second language acquisition (SLA). Second language learning is a conscious effort or a deliberate process of achieving new information by the learners. There is a considerable difference between native language and second language acquisition in a sense that acquisition of first language portrays the desire and innate ability of learners. According to Montgomery (2004) the specific constituents of L1, for example the specific elements of first language and innate capability to speak are critical factors related to its acquisition. However, in case of second language learning, learners face different cognitive makeup in different social and instructional situation. According to famous psychologist and educationist Maslo, language acquisition is a neuro-psychological process through which a child is able to acquire grammatical syntactic structure of his native language unconsciously. So, language acquisition is considered an essential part to make unity in all other languages. Children learn language due to their innate ability which is genetically programmed and organized in their mind (Chomsky, 2004, p. 17). According to Davis and Skilton (2004, p. 24), "the research investigation and different identities may be helpful for the teachers in pedagogical choices towards curriculum that can create prejudice practices and also proficient 
for educator conducts". LLS considered as learners' series of action are helpful in accomplishing learning tasks (Gu, 2003, p. 64). However, Griffiths (2008) puts learning strategies as conscious efforts of learners to explicit their own learning goals and improve the knowledge of target language.

\subsection{Language Learning Strategies (LLS)}

LLS refer to learners' deliberate effort during the process of learning second language and they help to develop learning more superior and suitable (Oxford, 1990; Koch, 2005). LLS have been classified and explained in different fields by many scholars during 1970s. Therefore, before classifying and defining LLS, there is great need to define the concept and meaning of strategy. This widely discussed term is defined by many researchers like O'Malley et al. (1985), Rubin (1975), and Oxford (1990) who were the prominent writers to classify different sub categories of techniques of learning foreign language. Language learning skills and attitudes, learning affairs, phases of learning, ethnic and intellectual differences, approach to learning, inspiration, and gender are the characteristics determined by researchers (Rubin et al., 1975, cited in Lee, 2010). There are different scales of measuring language learning strategies of learners and teachers. Strategy inventory of language learning (SILL) is the most commonly used scale used for measuring LLS. Green and Oxford (1995) opined that SILL is a system that exemplified the classification of strategies into 6 sub categories based on Oxford (1990). Oxford introduced six groups of strategies into 50 distributed statements:

\subsubsection{Cognitive Strategies}

These strategies are linked up with the cognitive framework of learners and they include but not limited to: logical judging, analyzing the statements in active use of language, practice, summarize and then analyzing including thinking.

\subsubsection{Meta-Cognitive Strategies}

These strategies are used to analyze and evaluate one's individual progress of language, and thinking about how to take the tasks of language by giving more attention to the errors of language.

\subsubsection{Memory-Related Strategies}

These strategies exemplify making groups for discussion, physically moving to review something, rhyming and imagery strategies especially related to the language in a structured way.

\subsubsection{Compensatory Strategies}

Compensatory strategies are related to form short or limited knowledge by guessing the meanings or synonyms of the conversation that relate to its contextual meanings.

\subsubsection{Affective Strategies}

These strategies are used to reduce the anxiety related to language context, and thinking how to encourage themselves and related to self-reward.

\subsubsection{Social Strategies}

Social strategies promote awareness of culture of the speakers, used to ask questions related to language, and show cooperation with native speaker.

The purpose of the SILL is to measure how students use strategies in three different ways for self-encouragement, self scoring and anxiety reduction especially in learning Literature. Cesure (2008, p. 49) stated the importance of this inventory in his study which was specially conducted to give focus on reliability and validity between strategy use. For this purpose, he used Turkish version of SILL which discovered correlation between the usage of Turkish and English versions of inventory. Similarly, the inventory has been used in other cultural contexts and educational settings.

\subsection{Language Education and English Literature}

English is used as second language in Pakistan. The proficiency of English language is considered a success towards education, fashion, profession and promotion at various academic fields and job positions. Teachers and textbooks are the two most reliable sources to get guidance at beginner and advanced level of language education. Along with these two sources, learners' preferences, choices and strategies are also important in developing their language proficiency skills. It is usually common trend to use different LLS while learning different language skills like reading, writing, listening, speaking, vocabulary and grammar. However, students who read English literature as an academic discipline, they tend to use fewer strategies while developing language proficiency skills. This study has focused its attention to study role and extent of language learning strategies used by ESL learners who adopt literature discipline to meet their academic goals. In Pakistani universities, students are 
enrolled in post graduate program of English literature and they study different literary genres like poetry, novel, drama, literary theories, Pakistani literature, postcolonial literature and American literature etc. It is a common assumption that linguistic competence in English language is hard to obtain while studying pure literature fields. However, like language students, literature students also adopt different activities, techniques and strategies to memorize and retrieve knowledge of literature.

\section{Methodological Framework}

\subsection{Research Design}

Research design is a process that enables researchers to use particular method by which research realizes its objectives. The study adopted descriptive framework. The data were collected and analyzed quantitatively. Quantitative research is used to obtain error free results near to accuracy and precision. The current study is planned by using the SILL (Strategy inventory for Language Learning) questionnaire organized by Oxford (1990).

\subsection{Sample of the Study}

The total sample of this study was 160 students of post graduate level, comprised of 40 male and 40 female learners from Islamia University Rahim Yar khan campus, 40 female learners from Khawaja Fareed College and 40 female students from Post graduate college for women, Rahim Yar Khan. All students were enrolled in English literature academic discipline. Random sampling technique was used to select and determine the sample of the accessible population framework. In random sampling EPSEM technique is followed where every member of the population has equal chances to become the part of sample. The simple random sample technique was used by putting all names in a flower basket and then taking out the names blindly out of the whole population framework.

\subsection{Measurement Tools and Covariates}

Observation and questionnaire were used as data collection instruments for this study. A questionnaire as data collection instrument developed by Oxford (1990) based on 'Strategy Inventory for Language Learning' (SILL) was used for this study. Though language used in inventory was assumed to be adequately understandable for the selected sample, but many respondents during pilot testing faced difficulty in developing good understanding of different items. Due to this reason original version was not used by the researchers as the language was difficult to understand. Consequently, modified version of SILL 7.0 (ESL/EFL) Oxford (1989) was used. There are 50 statements included in SILL (strategy inventory) with different scales like: "I do this-and I do such". Green and Oxford cited (1995, pp. 264-265) that SILL is a system that has further exemplified the classification of strategies into 6 categories based on Oxford (1990). The questionnaire was administered after ensuring its validation and achieving acceptable reliability level.

\section{Data Analysis}

During the survey, questionnaires were given to the students to be filled after obtaining their consent and clearing other ethical concerns. Descriptive statistic technique was used to calculate the frequency, percentage, mean score and standard deviation of the analyzed data. The analyzed data have been displayed and discussed as under:

Table 1. Use of memory strategies

\begin{tabular}{llllllllll}
\hline Direct Strategies & Student & Value & AT & UT & ST & UNT & NT & Overall Mean & Standard Deviation \\
\hline Memory & Male & N & 24 & 30 & 20 & 4 & 2 & 3.88 & 4.21 \\
strategies & & $\%$ & 30 & 37.5 & 25 & 5 & 2.5 & & \\
& Female & $\mathrm{N}$ & 28 & 42 & 7 & 3 & 0 & 4.19 & 1.98 \\
& & $\%$ & 35 & 52.5 & 8.75 & 3.75 & 0 & & \\
& Total & $\mathrm{N}$ & 52 & 72 & 27 & 7 & 2 & 4.04 & 3.09 \\
& & $\%$ & 32.5 & 45 & 16.9 & 4.3 & 1.3 & & \\
\hline
\end{tabular}

Note. $\mathrm{AT}=$ almost true; $\mathrm{UT}=$ usually true; $\mathrm{ST}=$ somewhat true; $\mathrm{UNT}=$ usually not true; $\mathrm{NT}=$ not at all true. 


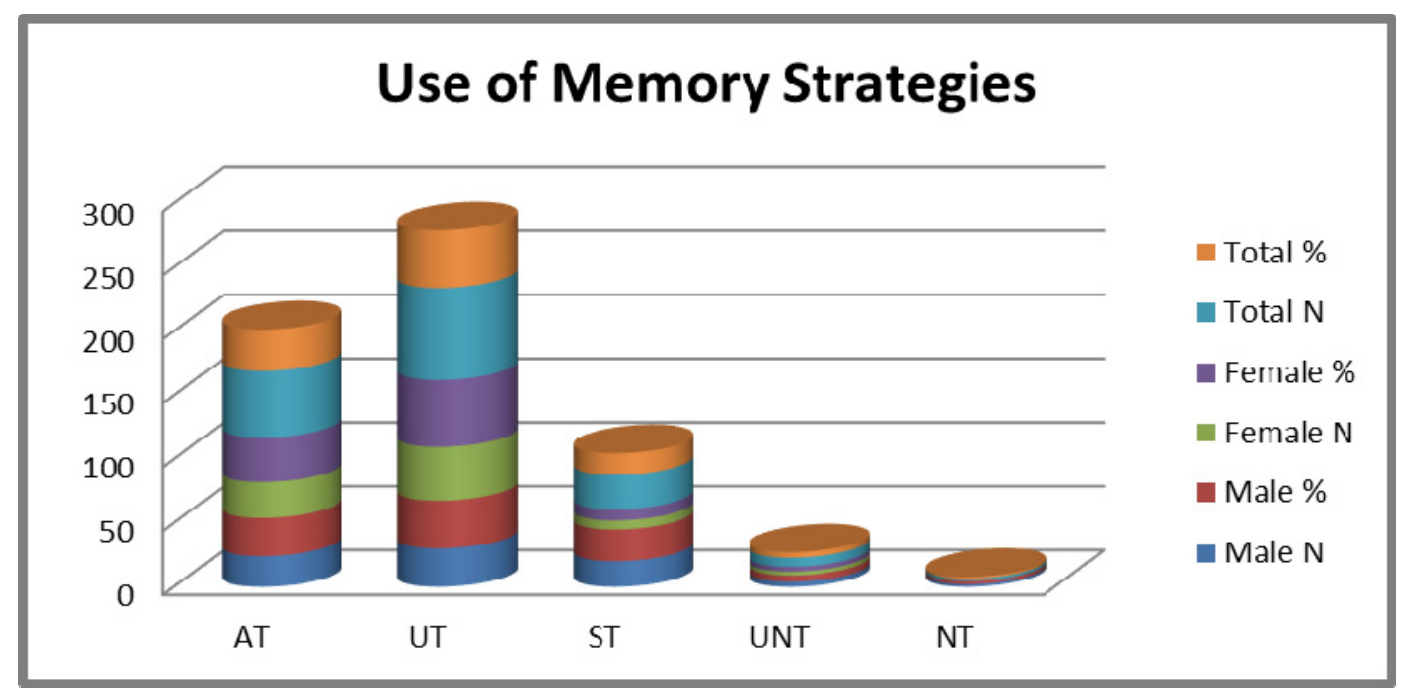

Figure 1. Use of memory strategies

The above-mentioned table shows the clear description about using memory strategies between male and female participants. From 80 male participants overall mean is 3.88; females indicated mean value 4.19 and the overall standard deviation/difference between them is 3.88. The total mean value was 4.04 that reveal that most of the statements regarding memory strategies were usually true to the participants. Data show that literature students used memory strategies quite often while learning literary subjects and acquiring English proficiency. However, these results revealed that females with their higher average use surpassed in using memory strategies. It is also evident from the result that females used memory strategies more frequently than male learners.

Table 2. Use of cognitive strategies

\begin{tabular}{llllllllll}
\hline Direct Strategies & Student & Value & AT & UT & ST & UNT & NT & Overall Mean & Standard Deviation \\
\hline Cognitive & Male & N & 22 & 28 & 13 & 7 & 10 & 3.65 & 3.18 \\
strategies & & $\%$ & 27.5 & 35 & 16.3 & 8.7 & 12.5 & & \\
& Female & N & 17 & 23 & 15 & 17 & 8 & 3.30 & 2.78 \\
& & $\%$ & 21.3 & 28.7 & 18.7 & 21.3 & 10 & & \\
& Total & N & 39 & 51 & 28 & 24 & 18 & 3.48 & 2.98 \\
& & $\%$ & 24.5 & 36.8 & 17.5 & 15 & 11.2 & & \\
\hline
\end{tabular}

Note. $\mathrm{AT}=$ almost true; $\mathrm{UT}=$ usually true; $\mathrm{ST}=$ somewhat true; $\mathrm{UNT}=$ usually not true; $\mathrm{NT}=$ not at all true

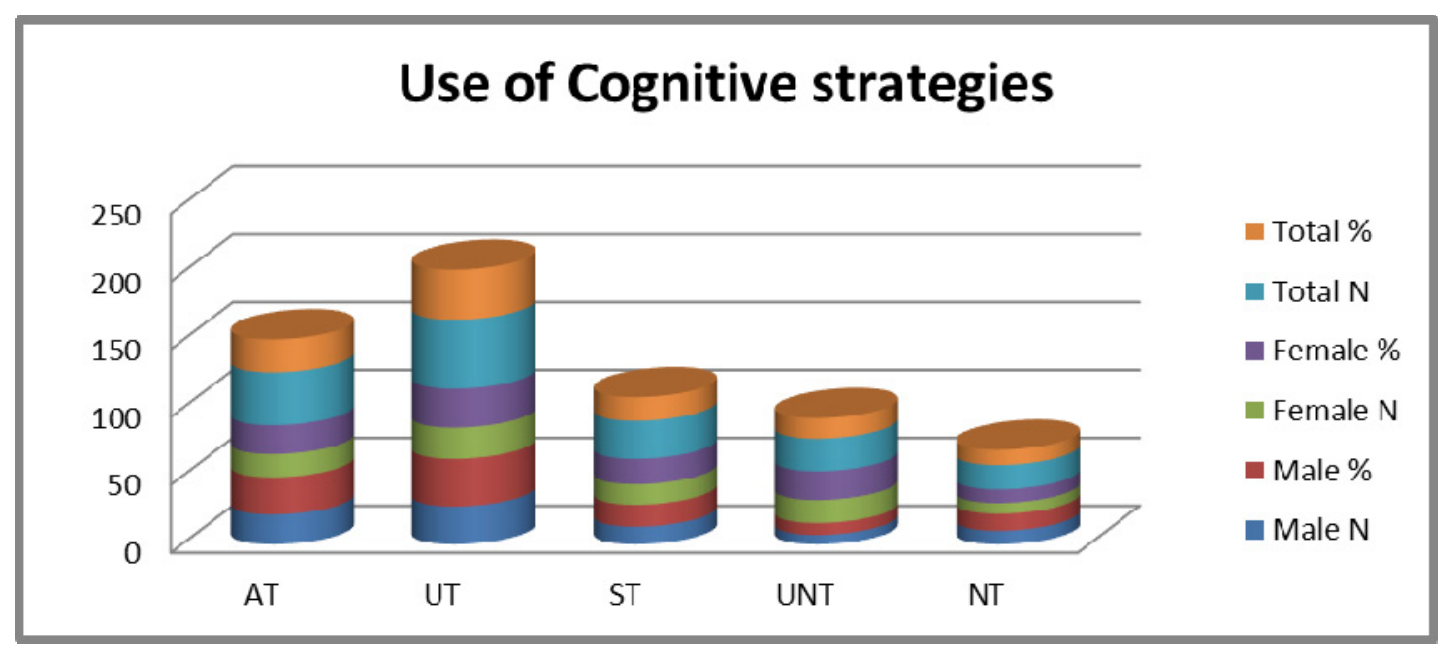

Figure 2. Use of cognitive strategies 
Cognitive strategies are considered very important in learning any second or foreign language. To find the differences and similarities among male and female language learners, frequency and mean scores of both genders were calculated. The results show that overall mean 3.48 is inclined towards the tendency of doing something on usual patterns. It means that most of the students told that it is usually true to them that they use cognitive strategies while learning literature and language skills. Data also show a minute difference between the usage of LLS among male and female learners; where male learners had higher mean value i.e., 3.65 than their female counterparts i.e., mean score 3.30. As compared to memory strategies, cognitive strategies were used less frequently by both male and female students.

Table 3. Use of compensatory strategies

\begin{tabular}{llllllllll}
\hline Direct Strategies & Student & Value & AT & UT & ST & UNT & NT & Overall Mean & Standard Deviation \\
\hline Compensatory & Male & N & 32 & 35 & 8 & 5 & 0 & 4.18 & 1.33 \\
strategies & & $\%$ & 40 & 43.7 & 10 & 6.3 & 0 & & \\
& Female & N & 21 & 34 & 13 & 10 & 2 & 3.78 & 1.04 \\
& & $\%$ & 26.3 & 42.5 & 16.2 & 12.5 & 2.5 & & \\
& Total & $\mathrm{N}$ & 53 & 69 & 21 & 15 & 2 & 3.98 & 1.19 \\
& & $\%$ & 33.2 & 43.1 & 13.1 & 9.4 & 1.2 & & \\
\hline
\end{tabular}

Note. $\mathrm{AT}=$ almost true; $\mathrm{UT}=$ usually true; $\mathrm{ST}=$ somewhat true; $\mathrm{UNT}=$ usually not true; $\mathrm{NT}=$ not at all true.

The findings declared that male students of literature used more compensatory strategies than female students. Table 3 shows information regarding compensatory strategies used by male and female learners. $40 \%$ male and $26.3 \%$ female learners told that they use compensatory strategies to the best of their perceptions. Overall mean score of all statements related to compensatory strategies among male learners was 4.18 , among female it was 3.78 and overall it reached 3.98. All these statistical figures give substantial proof that students had been well in practice to use compensatory strategies during their learning.

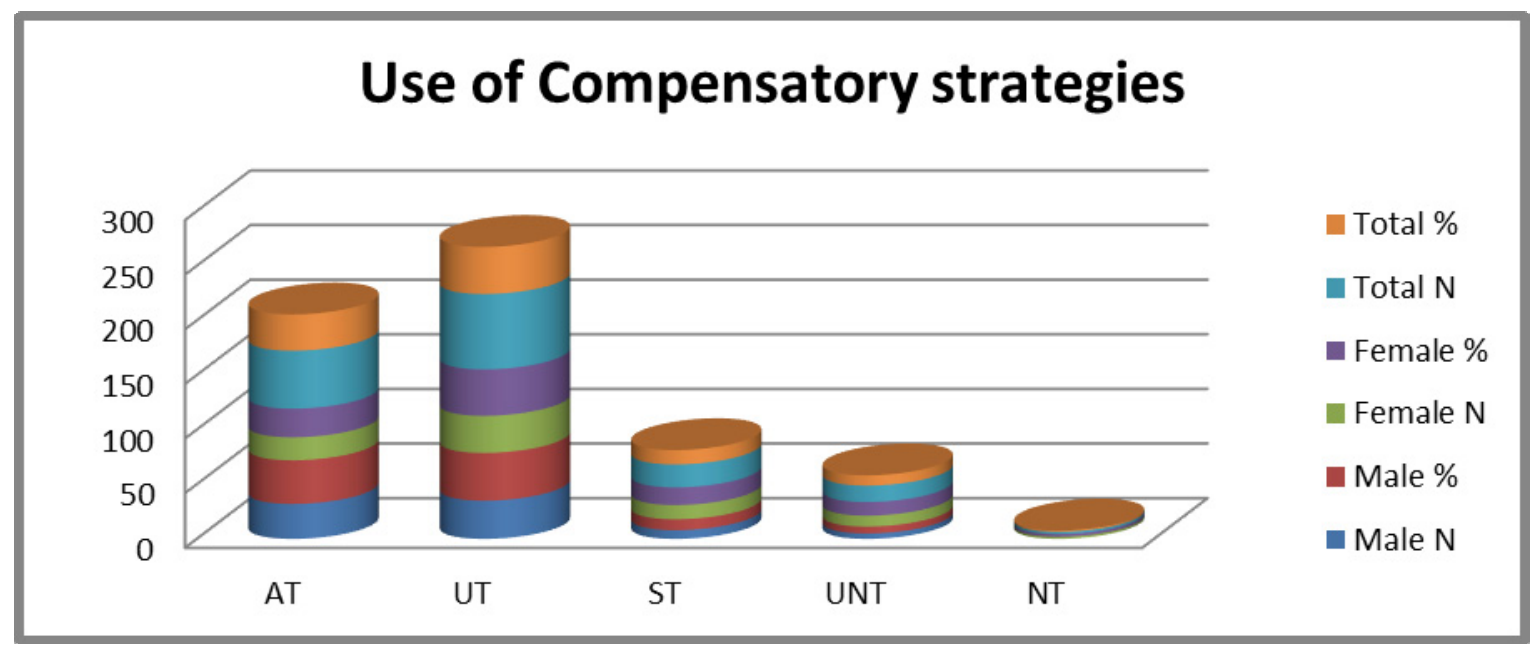

Figure 3. Use of compensatory strategies

Table 4. Use of meta-cognitive strategies

\begin{tabular}{llllllllll}
\hline Indirect Strategies & Student & Value & AT & UT & ST & UNT & NT & Overall Mean & Standard Deviation \\
\hline Meta-cognitive & Male & $\mathrm{N}$ & 26 & 23 & 16 & 13 & 2 & 3.73 & 1.00 \\
strategies & & $\%$ & 32.5 & 28.7 & 20 & 16.3 & 2.5 & & \\
& Female & $\mathrm{N}$ & 28 & 29 & 22 & 1 & 0 & 4.05 & 1.79 \\
& & $\%$ & 35 & 36.2 & 27.5 & 1.3 & 0 & & \\
& Total & $\mathrm{N}$ & 54 & 52 & 38 & 14 & 2 & 3.89 & 2.395 \\
& & $\%$ & 33.9 & 37.4 & 23.7 & 8.8 & 1.2 & & \\
\hline
\end{tabular}

Note. $\mathrm{AT}=$ almost true; $\mathrm{UT}=$ usually true; $\mathrm{ST}=$ somewhat true; $\mathrm{UNT}=$ usually not true; $\mathrm{NT}=$ not at all true. 


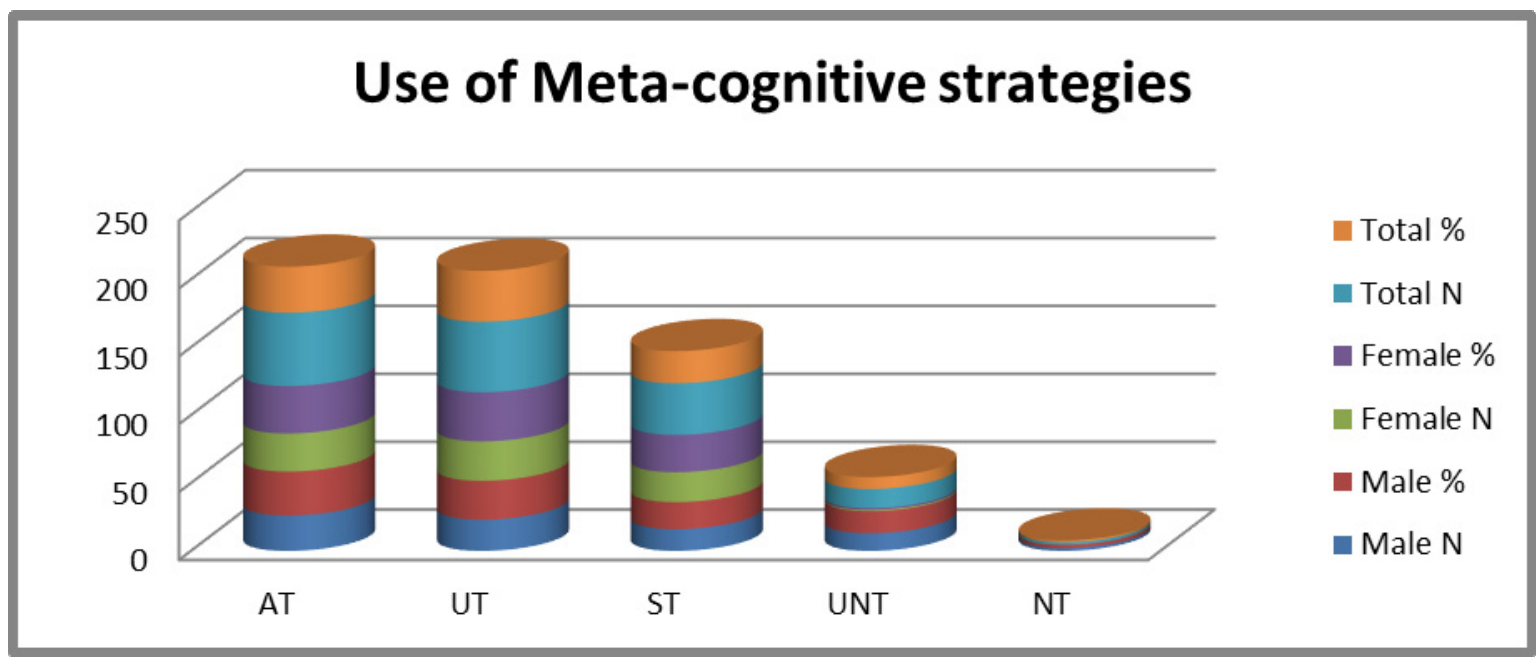

Figure 4. Use of meta-cognitive strategies

Regarding MET (Meta-cognitive) domain the obtained mean values declared that female students were dominant in all sub disciplines of meta-cognition. Table 4 describes the meta-cognitive strategies and its use at postgraduate level. Students opined differently regarding using meta-cognitive strategies which were asked through different statements. The overall mean calculated from different statements indicate that students utilized meta-cognitive strategies very frequently. Only small proportion of male learners was not habitual of using this strategy. Results indicate that female learners used meta-cognitive strategies to larger extent as compared to the male learners. Though, both genders use such strategies very frequently as their calculated mean score exhibits as 3.89 .

Table 5. Use of affective strategies

\begin{tabular}{llllllllll}
\hline Indirect Strategies & Student & Value & AT & UT & ST & UNT & NT & Overall Mean & Standard Deviation \\
\hline Affective strategies & Male & N & 20 & 30 & 10 & 18 & 2 & 3.60 & 2.29 \\
(AFF) & & $\%$ & 25 & 25 & 12.5 & 22.5 & 2.5 & & \\
& Female & N & 26 & 43 & 7 & 3 & 1 & 4.13 & 3.44 \\
& & $\%$ & 32.5 & 33.7 & 3.8 & 3.7 & 1.3 & & \\
& \multirow{2}{*}{ Total } & $\mathrm{N}$ & 46 & 73 & 17 & 21 & 3 & 3.87 & 2.87 \\
& & $\%$ & 28.8 & 29.4 & 8.3 & 13.1 & 1.9 & & \\
\hline
\end{tabular}

Note. $\mathrm{AT}=$ almost true; $\mathrm{UT}=$ usually true; $\mathrm{ST}=$ somewhat true; $\mathrm{UNT}=$ usually not true; $\mathrm{NT}=$ not at all true.

\section{Use of affective strategies}

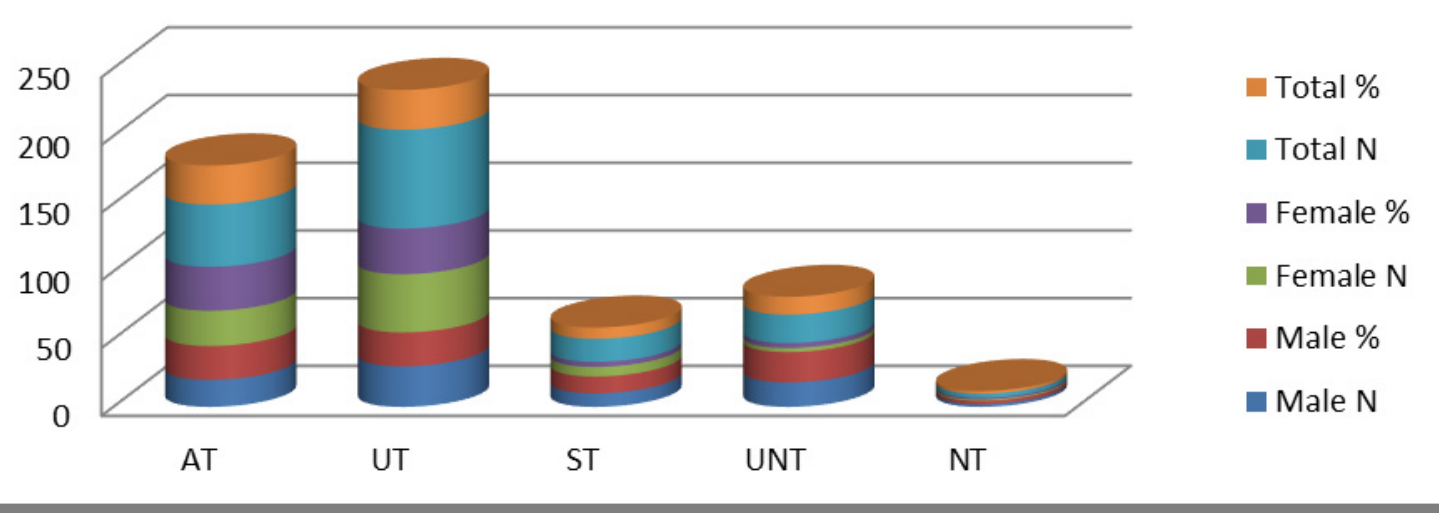

Figure 5. Use of affective strategies 
To investigate whether males were the most AFF strategy users or females, statistical findings were considered. The findings revealed the less frequent responses of male participants. The above Table 5 is used to find out the relationship of the participants with affective strategies that is subsequent trait of indirect strategies. The result obtained after statistical analysis reflects that female mean value was 4.13 , while 3.60 mean score was calculated for male learners. Female learners used affective strategies slightly more frequently than male learners.

Table 6. Use of Social strategies

\begin{tabular}{llllllllll}
\hline Indirect Strategies & Student & Value & AT & UT & ST & UNT & NT & Overall Mean & Standard Deviation \\
\hline Social Strategies & Male & N & 2 & 10 & 12 & 14 & 42 & 1.95 & 2.61 \\
(SOC) & & $\%$ & 2.5 & 12.5 & 15 & 17.5 & 52.5 & & \\
& Female & $\mathrm{N}$ & 22 & 36 & 18 & 5 & 9 & 4.09 & 2.34 \\
& & $\%$ & 27.5 & 45 & 22.5 & 6.3 & 11.2 & & \\
& Total & $\mathrm{N}$ & 24 & 46 & 20 & 19 & 51 & 3.02 & 2.48 \\
& & $\%$ & 15 & 23.8 & 23.7 & 11.8 & 31.7 & & \\
\hline
\end{tabular}

Note. $\mathrm{AT}=$ almost true; $\mathrm{UT}=$ usually true; $\mathrm{ST}=$ somewhat true; $\mathrm{UNT}=$ usually not true; $\mathrm{NT}=$ not at all true.

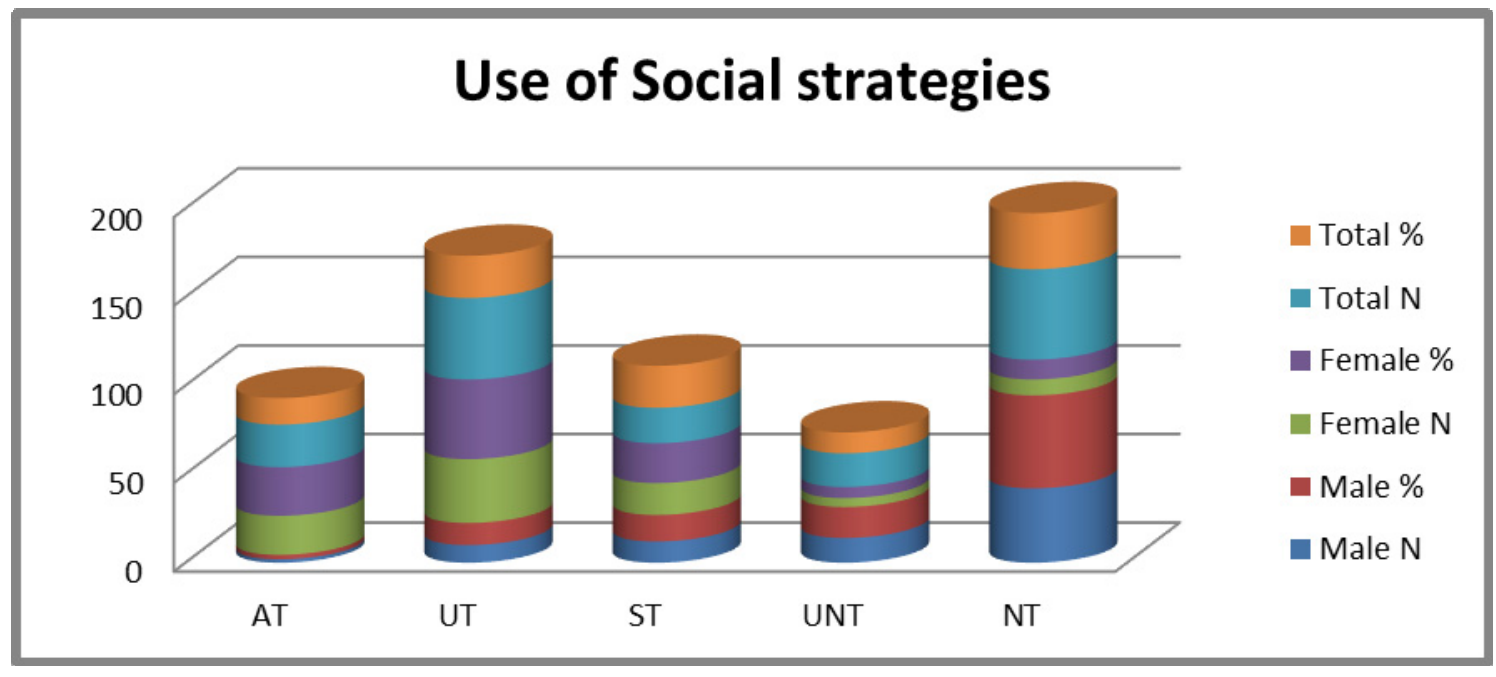

Figure 6. Use of social strategies

The last subscale of indirect strategies (domain) had very significant result in favor of female learners nevertheless a single item selected to show better response for male learners. Table 6 describes the extent of participants using social strategies at postgraduate level. The data reveal that male mean score was 1.95 , and female learners mean was calculated 4.09. According to obtained values female learners were found more interested in learning English culture. It also revealed that females are always emotional and welcome to unveil their emotion to others, and always show interest in learning about foreign cultures. It is concluded that males had not been using social strategies frequently whereas female students were using the same phenomenon to larger extent. On the whole, overall mean 3.02 explicates that students somewhat use SOC strategies during learning English in literature discipline.

\subsection{Discussions}

The questionnaires comprised the domain of direct and indirect strategies having 6 classifications: Memory strategy (MEM), cognitive strategy (COG), meta-cognitive (MET), compensation (COM), affective (AFF) and social strategies (SOC). The data set of analysis is being discussed according to the sub scales of LLS (language learning strategies). The main intention of the current study was to investigate the strategies used by learners at post graduate level. The initial question of the study sought the answer to explain different kinds of the LLS used by male and female students of literature at PG level. In order to obtain the answers of research questions, it was very necessary to select participants and tools which lead to get assumed destination. Therefore, statistics analysis was performed to know the most frequent use of LLS. After keen analysis of the given data it was found that female students were frequent users of memory, cognitive, affective and social strategies. They also used the 
meta-cognitive strategy but not as frequently as in other domain of strategies.

The first section of the questionnaire is named direct strategies which were further divided into subscales already mentioned above. Statements relevant to MEM described the overall mean of female participants was higher than their male counterparts. The mean score of females was higher in MEM while in males mean was lower i.e., 3.88. The average of both participants use of MEM strategy shows no similarity but it described that there is relationship between LLS and gender to achieve the goals of learning. The obtained results regarding COG domain were discussed with the help of tables clearly mentioning the difference of both genders using LLS skills. However, at some points males were at level of superiority so that obtained mean scores: male $=3.65 \%$ over female $=3.30 \%$, in Table 2 supported male students' higher position of using COG strategies. The findings of COG domain revealed female participants' superiority in using cognitive strategies to greater extent. However, in other similar past researches different results were found. Green and Oxford (1995) found that females were dominant users of LLS but in COG domain they found lightly better results than males. The present study also showed that although females are higher users of memory strategies but male are better in cognitive strategy use.

COM strategies are regarded as crucial mean to attain communication embodiment of all four skills (reading, writing, listening \& speaking), and in formal language setting their role is enhanced where communication of learners due to insufficient knowledge faced failure (Alptekin, 2007). To investigate the relationship of literature students and LLS the data were analyzed to know the mean score of strategy use. Table 3 signified that females used this strategy less frequently. From this section it was also observed that male participants are not frequent users of COM strategy though they were much better than last two listed domains. Table 3 showcases the dominancy of male learners as mean scores acquired from males were: male $=4.18$, over females $=3.78$. This can be concluded that although females are more strategic users in most of the strategic domains but in COM strategy males are much better.

The first sub section of LLS in indirect strategies was about meta-cognitive strategy (MET). The MET strategy domain represented that there was no similar response showed by both male and female participants; however, the MET domain described male mean score was at average level. Yet overall analysis of the data represented females' superiority in using MET strategies. To examine the relationship between MET strategy and participants of the study, Table 4 shows male mean value as 3.73 over female 4.05 that declared the difference of strategy use. The achieved mean values of both genders clearly described females were the more MET strategies users. The second subscale of indirect strategy is AFF strategy that investigated its most frequent use by the presented participants. Findings show that the mean value of male students was 3.60 and females was 4.13 regarding AFF strategy. Hence overall analysis indicated the female participants were found having dominant strategic behavior in this domain. Findings also indicate that the last scale of indirect strategy was again most frequently used by female participants. In SOC domain the top-rated scores were achieved by female learners. The results obtained regarding this domain marked huge difference and variance between the tendencies of both genders. The female learners rated the highest frequency of usage of SOC strategies, on the contrary male learners achieved the lowest regarding same phenomenon. According to Cesur (2008), females were superior over males in all subscales of language learning strategies. Further describing the differences of learning styles and strategies, his study concluded that females preferred styles of auditory learning while males were in favor of visual styles. The findings of the current study strengthen the results obtained in previous study conducted by Cesure (2008). Summing up the above all discussion female learners surpassed over male participants in using different LLS except compensation and cognitive strategies.

\section{Conclusion}

According to the results obtained from this study, there is affluent use of language learning strategies by ESL learners while learning English literature. Furthermore, findings reveal the strengthening of the general belief of female surpassed over male regarding LLS. It further describes that female learners of PG level adopt positive language learning strategies which are statistically evident. On the whole, students of literature discipline treat literature subjects differently based upon their personal likeness and educational priority. They oftentimes use learning strategies just to fulfill the study demands and avoid psychological monotony. They study literature subjects as it is made compulsion upon them to study them. Their interest and attitude sometimes do not match with this academic requirement. They learn literature just for the sake of getting good marks despite achieving no or low language proficiency. English literature program may bring negative effects not only on course implementation but students real language proficiency level would be at risk (Krishnasamy, 2015). The current study attempted to measure learners' attitudes, preferences and choices while learning language through literature discipline. The findings divulge appeasing results that students acquire literature and language skills quite enthusiastically. They use multi-scaled language learning strategies to meet their academic and 
professional demands. However, the tendency of strategy users was found different among male and female learners. Several studies such as Yang (2007) attained similar results while doing research on language style and LLS, similar to the results of the current study where female learners got superiority over males regarding the use of LLS. However, it is cited in the study of Yalçın (2006) that there is no difference in the use of LLS and gender participants. On the other hand, in the current study, it is statistically proved that there is substantial difference found between male and female students regarding using LLS. The study concludes with the strong suggestion for other researchers to undergo similar research at different level of education among learners belonging to different social class (urban vs. rural) and educational setting (private vs. government). Furthermore, there is a strong need to measure the impact of different LLS in an experimental research design.

\section{References}

Alptekin, C. (2007). Foreign language learning strategy choice: Naturalistic versus instructed language acquisition [Electronic version]. Journal of Theory and Practice in Education, 3(1), 4-11.

Baily, C. A. (1996). Unobtrusive computerized observation of compensation strategies for writing to determine the effectiveness of strategy instruction. In R. L. Oxford (Ed.), Language learning strategies around the world: Cross-cultural perspectives (Tech. Rep. No. 13, pp. 141-150).

Brown, H. D. (2000). Principles of language learning and teaching. White Plains, NY: Wesley Longman.

Cesur, O. (2008), Üniversite hazırlık sınıfı örgencilerinin yabancı dil öğrenme stratejileri, ögrenme stili tercihi ve yabancı dil akademik başarısı arasındaki açıklayıcı ve yordayıcı ilişkiler örüntüsü. Unpublished Ph.D. Thesis, Yıldız Teknik Üniversitesi, İstanbul.

Chomsky, N. (2004). Knowledge of Language as a Focus of Inquiry. In B. Lust \& C. Foley (Eds.), First language acquisition: The essential readings (pp. 15-24). Malden: MA: Blackwell Pub.

Davis, K. A., \& Skilton-Sylvester, E. (2004). Looking back, taking stock, moving forward: Investigating gender in TESOL. TESOL Quarterly, 38(3), 381-404. https://doi.org/10.2307/3588346

Ehrlich, S. (1997). Gender as social practice: Implications for second language acquisition. Studies in Second Language Acquisition, 19(4), 421-446. https://doi.org/10.1017/S0272263197004014

Fink, L. D. (2003). Creating Significant learning Experiences: An Integrated Approach to Designing College Courses. San Francisco, CA: Jossey Bass Publishers.

Freed, A. F. (1995). Language and gender. Annual Review of Applied Linguistics, 15, 3-22. https://doi.org/10.1017/S0267190500002580

Gass, S. M., \& Selinker, M. (Ed.). (2008). Second Language Acquisition. New York \& UK: Routledge. https://doi.org/10.1057/9780230240780_6

Graham, S. (1997). Effective Language Learning. Clevedon: Multilingual Matters Ltd.

Green, J. M., \& Oxford, R. L. (1995). A closer look at learning strategies, L2 Proficiency and Gender. TESOL Quarterly, 29(2), 261-297. https://doi.org/10.2307/3587625

Griffiths, C. (2008). Lessons from Good Language Learners. Cambridge: Cambridge University Press. https://doi.org/10.1017/CBO9780511497667

$\mathrm{Gu}, \mathrm{Y}$. (2003). Fine brush and freehand: the vocabulary learning art of two successful Chinese EFL learners. TESOL Quarterly, 37, 73-99. https://doi.org/10.2307/3588466

Karatay, M. (2006). Turkish adult language learners' preferences in language learning strategies. Unpublished M.A. Thesis, Uludağ Üniversitesi, Bursa.

Koch, A. (2005). What are Language Learning Strategies and how can they contribute to a better learning? Seminar Paper. Germany: Grin Verlag. 6.

Krishnasamy, J. (2015). An Investigation of Teachers' Approaches Employed in Teaching the English Literature. Asian Journal of Education and e-Learning, 2(3).

Lee, C. K. (2010). An overview of language learning strategies. Arecls, 7, 132-152.

Montgomery, S. (2004). Of Towers, Walls, and Fields: Perspectives on Language in Science. Science, 303, 1333. https://doi.org/10.1126/science.1095204

O’Malley, J. M., Chamot, A. U., Stewner-Manzanares, G., Russo, R. P., \& Kupper, L. (1985). Learning strategy applications with students of English as a second language. TESOL Quarterly, 19(3), 557-584. 
https://doi.org/10.2307/3586278

Oxford, R. (1989). Use of language learning strategies: A synthesis of studies with implications for teacher training. System, 17, 235-247. https://doi.org/10.1016/0346-251X(89)90036-5

Oxford, R. L. (1990). Language Learning Strategies: What Every Teacher Should Know. Boston: Heinle \& Heinle.

Oxford, R. L. (1993). Gender differences in styles and strategies for language learning: What do they mean? Should we pay attention? In J. Alatis (Ed.), Strategic Interaction and Language Acquisition: Theory, Practice, and Research (pp. 541-557). Washington, DC: Georgetown University Press.

Oxford, R. L., \& Burry-Stock, J. A. (1995). Assessing the use of language learning strategies worldwide with the ESL/EFL version of the Strategy Inventory for Language Learning (SILL). System, 23, 1-23. https://doi.org/10.1016/0346-251X(94)00047-A

Oxford, R. L., Ehrman, M., \& Nyikos, M. (1988). Vive la difference? Reflection on sex differences in use of language learning strategies. Foreign Language Annals, 21(4), 321-329. https://doi.org/10.1111/j.1944-9720.1988.tb01076.x

Oxford, R. L., \& Burry-Stock, J. A. (1995). Assessing the use of language learning strategies worldwide with the $\mathrm{ESL} / \mathrm{EFL}$ version of the Strategy Inventory for Language Learning (SILL). System, 23(1), 1-23. https://doi.org/10.1016/0346-251X(94)00047-A

Rubin, J (1975). What the 'good language learner' can teach us. TESOL Quarterly, 9, 41-51. https://doi.org/10.2307/3586011

Shmais, W. A. (2003). Language learning strategy use in Palestine. TESL-EJ, 7(2), A-3.

Sunderland, J. (2000). Issues of language and gender in second and foreign language education. Language Teaching, 33(4), 203-223. https://doi.org/10.1017/S0261444800015688

Tabanlığlu, S. (2003). The Relationship between learning styles and language learning strategies of pre-intermediate EAP participants. Unpublished M.A. Thesis, Middle East Technical University, Ankara.

Yang, M. N. (2007). Language learning strategies for junior college students in Taiwan: Investigating ethnicity and proficiency. Asian EFL Journal, 9(2).

\section{Copyrights}

Copyright for this article is retained by the author, with first publication rights granted to the journal.

This is an open-access article distributed under the terms and conditions of the Creative Commons Attribution license (http://creativecommons.org/licenses/by/4.0/). 